\title{
Thermal utilization of mixtures of bone waste
}

\author{
Paweł Staroń, Zygmunt Kowalski, Kinga Krupa-Żuczek, Zbigniew Wzorek \\ Cracow University of Technology; Institute of Chemistry and Inorganic Technology, ul. Warszawska 24, 31-155 Kraków, \\ Poland, e-mail: pstaron@chemia.pk.edu.pl
}

\begin{abstract}
The results of a research related to the physico - chemical properties of the mixture of bone - waste and their ingredients have been presented. The mixtures was made up from waste: bovine bones, pork bones, bone sludge and bone meal. The content of the individual waste in the mixtures was selected on the basis of the heat of the combustion of the mixture and the amount of the waste produced in a meat processing plant. The heat of the combustion has been determined by the calorimeter, the content of phosphorus by spectrophotometric method, calcium by titration and phase composition by $\mathrm{X}$ - ray diffraction.

The investigations confirmed that pork bones have the highest heat of the combustion $17 \mathrm{MJ} / \mathrm{kg}$ because of a big amount of fats. The analyzed waste has contained on average $16.5 \mathrm{wt} \%$ phosphorus and above $30 \mathrm{wt}$ $\%$ calcium. X - ray diffraction method has proved that in bone waste one phase - hydroxyapatite occurs.
\end{abstract}

Keywords: bone-waste, phosphorous, calcium, calorimeter, heat of combustion.

\section{INTRODUCTION}

There are a lot of different kinds of waste products generated by meat industry. The most popular method of the utilization of animal waste is its processing into meatbone meals. A meat-bone meal has a high heat of combustion averaged $24 \mathrm{MJ} / \mathrm{kg}$ and it is comparable with the heat of the combustion of power coal (brown coal). A meatbone meal (MBM) contains a large amount of hydrogen and oxygen. Hydrogen causes an increase of the heat of combustion. The content of oxygen (approximately $41 \mathrm{wt} \%$ ) makes the introduction of MBM into the combustion chamber with small amounts of air possible and has an effect on the high reactivity of MBM. The organic part of a meat-bone meal contains almost $40 \mathrm{wt} \%$ of oxygen which is necessary to the combustion process. Sulphur also occurs in the organic part on average $0.1 \mathrm{wt} \%$ and it burns completely. Pyrolyzates are free of sulphur compounds ${ }^{\mathbf{1}, \mathbf{2}}$.

Thermal utilization is a more recent trend leading to the production of ashes consisting mainly of hydroxyapatite (HAp) which is contaminated in minute quantities of sodium, aluminium and silicon ${ }^{3-6}$. The ashes obtained at the temperature of $950^{\circ} \mathrm{C}$ have a content of phosphorus on average $16.5 \mathrm{wt} \%$ and calcium on average $39.3 \mathrm{wt} \%$. The $\mathrm{X}$-Ray analyses has demonstrated that hydroxyapatite is the only crystalline phase. The product obtained as a result of roasting is homogeneous in respect of chemical constitution. It is pure and free of heavy metals ${ }^{7}$.

The method of utilizing a particular type of waste is strictly determined by the European Union Directives, and depends on the category a particular type of waste belongs to. The first category is called special risk. The meat-bone meal and all elements of the body of animals suspected of a possibility of BSE disease belong to theis category and the only way of utilization is combustion at the temperature minimum $850^{\circ} \mathrm{C}$ for $2 \mathrm{~s}^{8-10}$. The second category is called a high risk and contains animals' byproducts, droppings, the content of the digestive track and deposits obtained in sewage disposal. The waste from the second category must be utilized by thermal utilization. The third category is the category of low risk and contains bone sludge, leather, horns, hoofs, pork bristle, blood of animals different from ruminant. This category also includes the meat of animals used for humans consumption or which is not usable but has no infectious disease. The waste from category III can be utilized through the combustion or converted into the feed, biogas or compost ${ }^{7,11}$.

Thermal utilization is used for render harmless the organic waste such as meat-bone meal, fats and the other animals' by-products. Thermal utilization takes advantage of rotary furnaces that worked over $1000^{\circ} \mathrm{C}$.

The aim of this paper has been to select the composition of animal waste mixtures obtained in PPHU DudaBis to have a high heat of combustion of the waste and to make thermal utilization in a rotary furnace possible.

\section{EXPERIMENTAL PART}

\section{Characteristic of raw material}

Technical bones and food bones come from the meat that could be eaten by people. Preservation depends on freezing, pickling, boiling (for technical bones) in water at the temperature about $100^{\circ} \mathrm{C}$ or autoclaving over $100^{\circ} \mathrm{C}$ under pressure. Contamination of organic bones is about $1-1.5$ wt $\%$, inorganic about $0.5-1.0$ wt $\%$ (earth, metals, plastics). The fresh, raw bones should be kept at temperature $0-12^{\circ} \mathrm{C}$ and air humidity of $85 \mathrm{wt} \%$. Technical bones can be stored longer than 48 hours, but they have to be preserved ( $20 \%$ solution of whitewash with $1 \%$ of chlorinated lime and $0.5 \%$ carbolic acid) ${ }^{\mathbf{1 2}}$.

The material analyzed in the research was meat-bone waste: pork bones, bovine bones, bone pulp and bone sludge. The waste was delivered as a raw material in four $3 \mathrm{~kg}$ boxes. The material $(100 \mathrm{~g})$ was disintegrated and dried for constant weight. The humidity content was determined and dry material was grinded in an electrical mill. The content of phosphorus total, calcium and phase composition were determined. The results of the analyses are presented in Table 1 and Figure 1.

\section{Description of the research.}

The determination of phosphates was carried out with the use of a Marcel Media spectrophotometer by the spectrophotometric method. In this case extraction was car- 
Table 1. Mass fraction of the defined ingredients in particular raw waste types

\begin{tabular}{|l|c|c|c|c|}
\hline Raw material & $\begin{array}{c}\text { Humidity content } \\
{[\mathrm{wt} \%]}\end{array}$ & $\begin{array}{c}\text { Calcium content } \\
{[\mathrm{wt} \%]}\end{array}$ & $\begin{array}{c}\text { Phosphorous content } \\
{[\mathrm{wt} \%]}\end{array}$ & $\begin{array}{c}\text { Heat of combustion } \\
{[\mathrm{MJ} / \mathrm{kg}]}\end{array}$ \\
\hline Bovine bones & 37.6 & 18.0 & 8.5 & 13 \\
\hline Pork bones & 40.3 & 13.8 & 6.7 & 17 \\
\hline Bone sludge & 51.6 & 23.7 & 11.5 & 7.8 \\
\hline Pulp & 38.4 & 24.5 & 11.8 & 7.5 \\
\hline
\end{tabular}

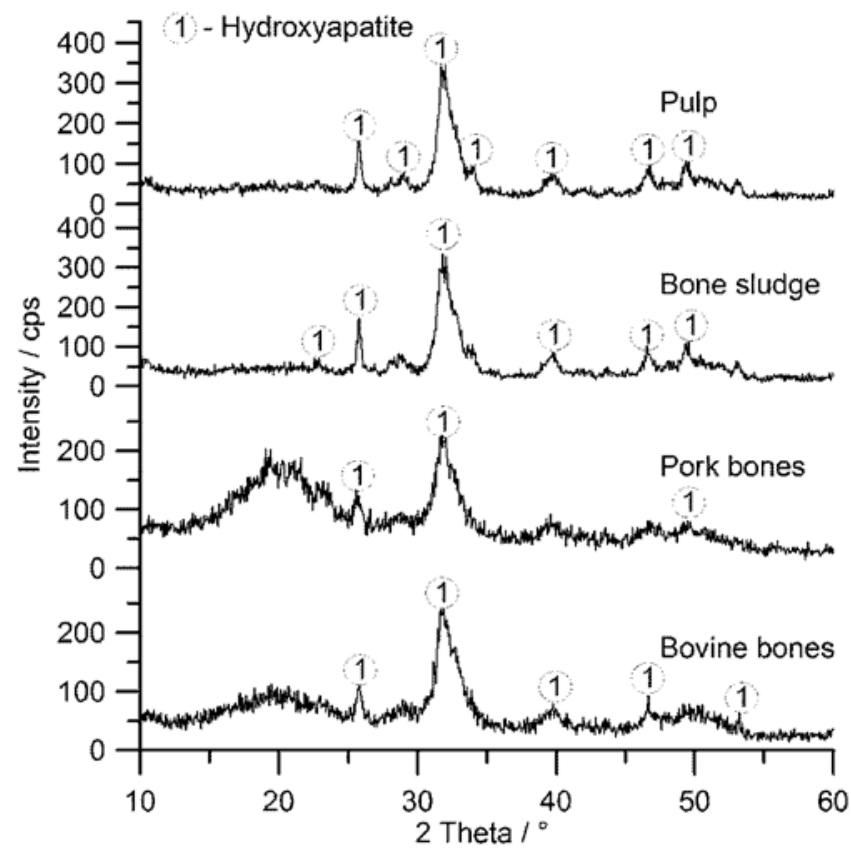

Figure 1. A diffractogram of raw material from PPHU Duda-Bis

ried out with concentrated acids (chloric and nitric), ratio $1: 3$, at the boiling point, whereas the determination of calcium was conducted by the complexometric titration with disodium versenate according to the norms ${ }^{13,14}$. The humidity content was determined with the use of the WPS210S model of a RADWAG weight dryer, at the temperature of $105^{\circ} \mathrm{C}$, and the sampling time of $5 \mathrm{sec}$ onds. Drying of the samples lasted for 2 hours on average. The phase composition was determined by the X-Ray method on the Philips X'Pert diffractometer equipped with a graphite monochromator PW 1752/00.
The waste was comminuted, dried and ground in an electrical mill and then the corresponding mixtures were made up. The heat of the combustion was determined with the help of the calorimeter KL-12Mn model of a Precyzja-Bit ${ }^{15}$.

The next step was the preparation of the experiment design. It was necessary for the determination of the mixture composition for all four kinds of the waste generated in PPHU Duda-Bis. The mixture had to be characterized by the possibly greatest value of the heat of combustion. The most important assumption of the experiment design was the amount of bovine bones. That amount was proportional to the amount of bovine bones generated in PPHU Duda-Bis. Bovine bones take up the $10 \mathrm{wt} \%$ of all bone waste. The experimental design was generated in the STATISTICA program and it served the preliminary mass composition of mixtures ${ }^{\mathbf{1 6}}$. The mixture prepared in this way was analyzed to the determined heat of combustion (Table 2). The data were introduced into the STATISTICA program to determine the distribution of the heat of combustion. It has made the selection of the proper composition of the searched mixture possible (Fig. 2).

Finally, three mixtures were chosen and made out (Table 3). The heat of the combustion of those mixtures were determined. In mixture I all ingredients were added in the same mass amounts. The composition of mixture II was defined on the basis of distribution of heats of combustion. It is a mixture with the greatest value of the heat of combustion. The composition in mixture III was proportional to the amount of waste generated in PPHU DudaBis.

Mixtures I, II and III were burnt in an electrical kiln at the temperature $\left[{ }^{\circ} \mathrm{C}\right]: 600,800,900$ for 2 hours in air atmosphere. The colour of the ashes depends on the tem-

Table 2. Assumptions of mixtures compositions - an experimental design

\begin{tabular}{|c|c|c|c|c|c|}
\hline \multirow{3}{*}{ Number of mixture } & \multicolumn{4}{|c|}{ wt $\%$} & \multirow{3}{*}{$\begin{array}{c}\text { Heat of } \\
\text { combustion } \\
{[\mathrm{MJ} / \mathrm{kg}]}\end{array}$} \\
\hline & $\mathrm{X} 1$ & $\mathrm{X} 2$ & $\mathrm{X3}$ & $\mathrm{X} 4$ & \\
\hline & Bovine bones & Pork bones & Bone sludge & Pulp & \\
\hline 1 & 1 & 0 & 0 & 0 & 12.9 \\
\hline 2 & 0 & 1 & 0 & 0 & 17.1 \\
\hline 3 & 0 & 0 & 1 & 0 & 7.8 \\
\hline 4 & 0 & 0 & 0 & 1 & 7.5 \\
\hline 5 & 0.5 & 0.5 & 0 & 0 & 14.2 \\
\hline 6 & 0.5 & 0 & 0.5 & 0 & 9.9 \\
\hline 7 & 0.5 & 0 & 0 & 0.5 & 9.8 \\
\hline 8 & 0 & 0.5 & 0.5 & 0 & 12.4 \\
\hline 9 & 0 & 0.5 & 0 & 0.5 & 12.1 \\
\hline 10 & 0 & 0 & 0.5 & 0.5 & 7.6 \\
\hline 11 & 0.333 & 0.333 & 0.333 & 0 & 12.1 \\
\hline 12 & 0.333 & 0.333 & 0 & 0.333 & 11.4 \\
\hline 13 & 0.333 & 0 & 0.333 & 0.333 & 9.0 \\
\hline 14 & 0 & 0.333 & 0.333 & 0.333 & 10.7 \\
\hline 15 & 0.25 & 0.25 & 0.25 & 0.25 & 11.0 \\
\hline
\end{tabular}


Table 3. The composition of the mixtures of bone waste (dry mass)

\begin{tabular}{|l|c|c|c|c|c|}
\hline $\begin{array}{l}\text { Number of } \\
\text { mixture }\end{array}$ & $\begin{array}{c}\text { Bovine bones } \\
{[\mathrm{wt} \%]}\end{array}$ & $\begin{array}{c}\text { Pork bones } \\
{[\mathrm{wt} \%]}\end{array}$ & $\begin{array}{c}\text { Bone } \\
\text { sludge } \\
{[\mathrm{wt} \%]}\end{array}$ & $\begin{array}{c}\text { Pulp } \\
{[\mathrm{wt} \%]}\end{array}$ & Heat of combustion [MJ/kg] \\
\hline I & 26.0 & 26.0 & 22.0 & 26.0 & 11.4 \\
\hline II & 10.0 & 45.0 & 22.5 & 22.5 & 12.5 \\
\hline III & 10.0 & 30.0 & 30.0 & 30.0 & 11.0 \\
\hline
\end{tabular}

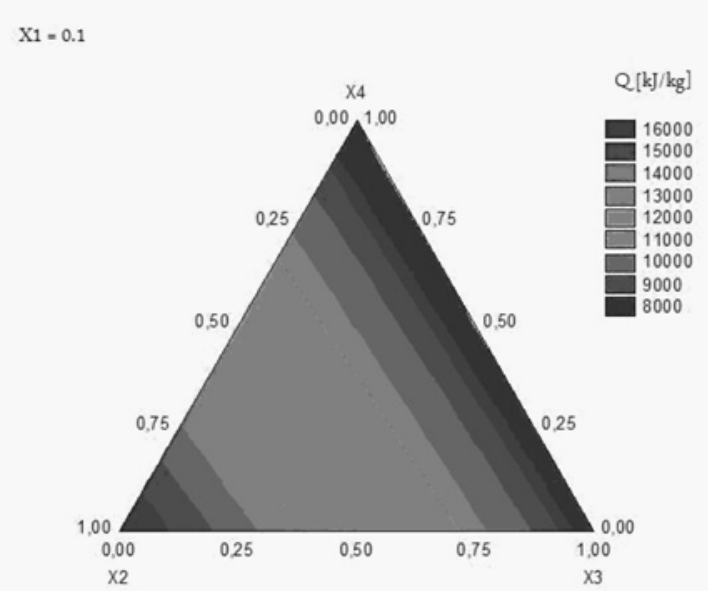

Figure 2. Distribution of the heat of combustion created by the STATISTICA program

perature of burning. An increase in the roasting temperature of the materials is accompanied by an increased degree of HAp crystallinity. The products of calcining were comminuted and homogenized in a mortar to get the size of grain less than $0.15 \mathrm{~mm}$.

Samples of mixture III were also roasted in a rotary furnace (Fig. 3) (cocurrent, quarter-technical scale) which consists of the feeder, combustion chamber with a gas burner and control unit. The variables of the process: temperature $900^{\circ} \mathrm{C}$, charge $-2 \mathrm{~kg} / \mathrm{h}$, rotation of furnace $0.5 / \mathrm{min}$. Samples coming from the rotary furnace demonstrated a smaller degree of calcining and the degree of HAp crystallinity was also smaller. The difference between the degree of calcining in the rotary furnace and the chamber kiln results from different times of burning. The samples were roasted for $30 \mathrm{~min}$ in the rotary furnace and 2 hours in the chamber kiln.

\section{Discussion about the results}

The heat of the combustion of mixtures I, II and III is over $11[\mathrm{MJ} / \mathrm{kg}]$ (Table 3) and it depends on the composition of mixture. The mixture with the predominant amount of pork bone has the greatest heat of combustion.

The ashes produced from bone waste as a result of burning contained on average $16 \mathrm{wt} \%$ phosphorus and 36 wt $\%$ calcium (Table 4$)$. These amounts increase when the temperature increases. The composition of the mixtures has no significant influence on the content of phosphorus and calcium.

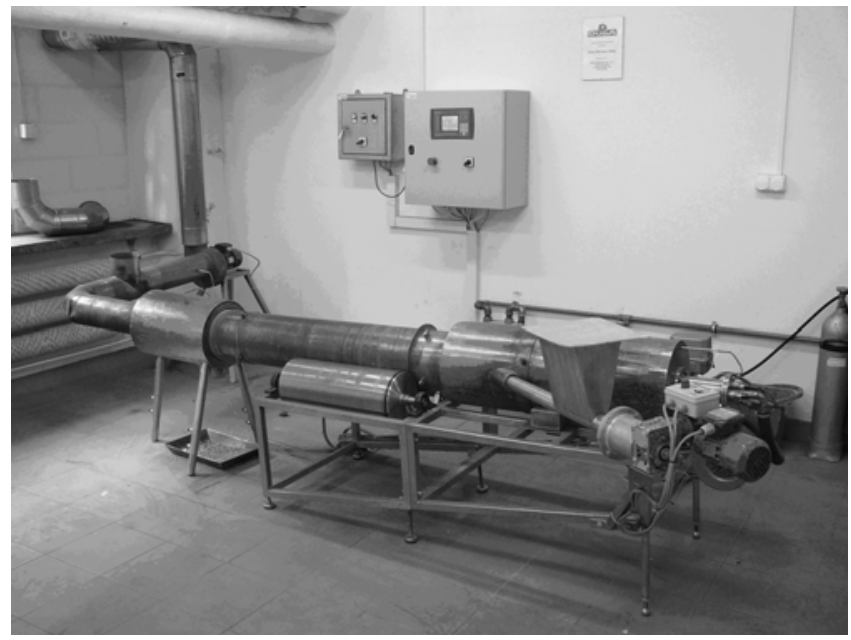

Figure 3. The experimental rotary furnace

The X-Ray spectra for the mixtures (Fig. 4-6) shows that hydroxyapatite is the only crystalline phase of the ashes. An increase in the roasting temperature of the materials leads to increasing the degree of HAp crystallinity, which reflects an increase in the number of counts in the presented diffractograms.

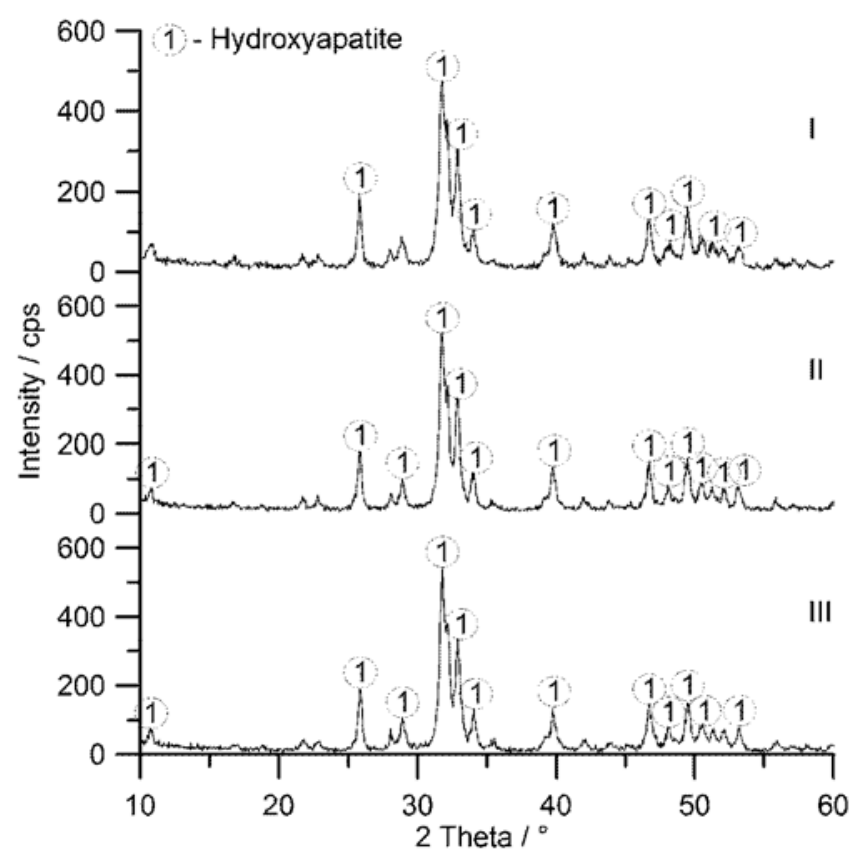

Figure 4. The diffractogram of the ash from mixtures I,II and III calcined at $600^{\circ} \mathrm{C}$

Table 4. The content of calcium and phosphates in the ashes generated by burning in the chamber kiln

\begin{tabular}{|c|c|c|c|c|c|c|}
\hline \multirow{3}{*}{ The kind of mixture } & \multicolumn{6}{|c|}{ Temperature of roasting } \\
\hline & \multicolumn{2}{|c|}{$600^{\circ} \mathrm{C}$} & \multicolumn{2}{|c|}{$800^{\circ} \mathrm{C}$} & \multicolumn{2}{|c|}{$900^{\circ} \mathrm{C}$} \\
\hline & $\begin{array}{c}\mathrm{Ca} \\
{[\mathrm{wt} \%]}\end{array}$ & $\begin{array}{c}\mathrm{P} \\
{[\mathrm{wt} \%]}\end{array}$ & $\begin{array}{c}\mathrm{Ca} \\
{[\mathrm{wt} \%]}\end{array}$ & $\begin{array}{c}\mathrm{P} \\
{[\mathrm{wt} \%]}\end{array}$ & $\begin{array}{c}\mathrm{Ca} \\
{[w t \%]}\end{array}$ & $\begin{array}{c}\mathrm{P} \\
{[\text { wt \%] }}\end{array}$ \\
\hline Mixture I & 36.7 & 16.3 & 37.4 & 17.1 & 37.8 & 17.3 \\
\hline Mixture II & 36.4 & 16.8 & 37.2 & 17.2 & 38.1 & 17.5 \\
\hline Mixture III & 36.4 & 16.7 & 37.1 & 17.3 & 37.8 & 17.7 \\
\hline
\end{tabular}




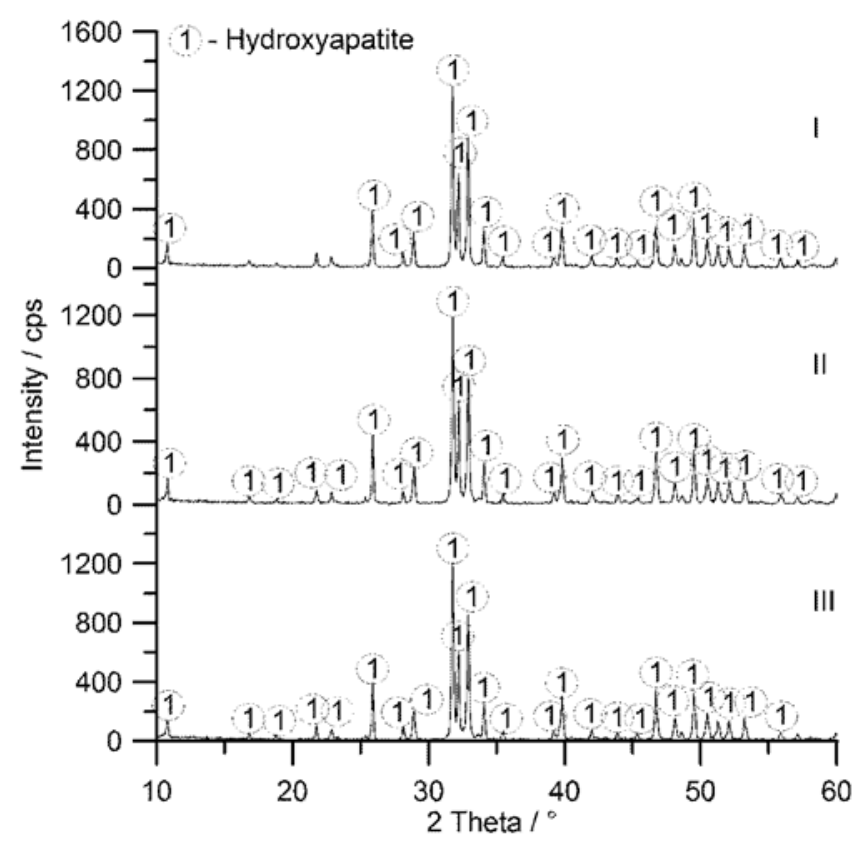

Figure 5. The diffractogram of the ash from mixtures I,II and III calcined at $800^{\circ} \mathrm{C}$

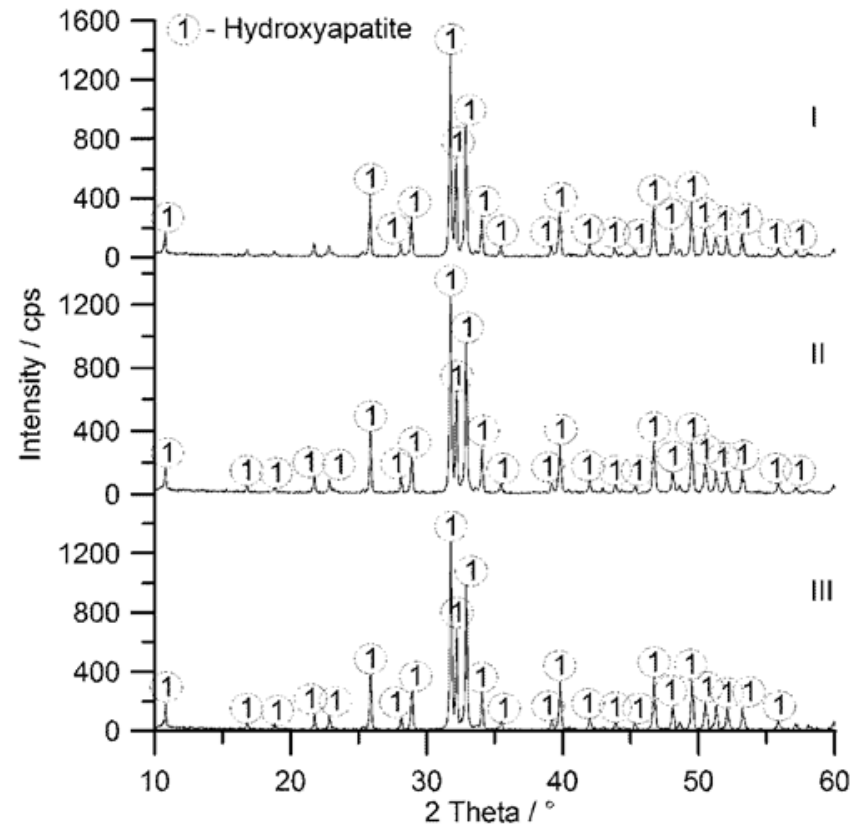

Figure 6. The diffractogram of the ash from mixtures I,II and III calcined at $900^{\circ} \mathrm{C}$ comminution and second roasting

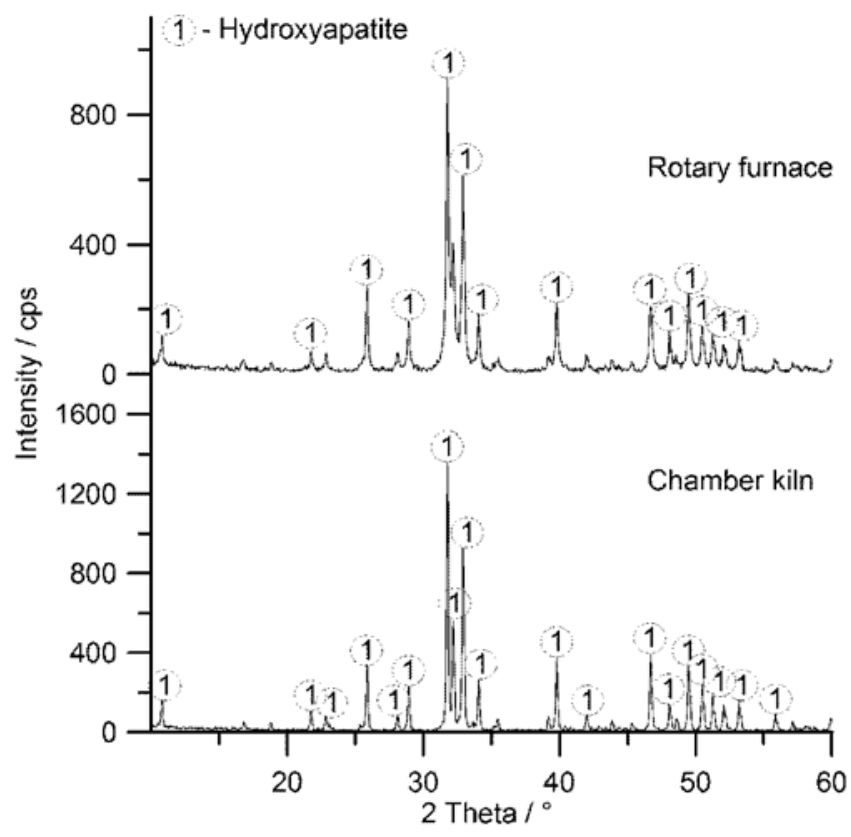

Figure 7. The diffractogram of the ash from mixture III calcined at $900^{\circ} \mathrm{C}$ in the rotary furnace

Table 5. The content of phosphorous and calcium in the ash roasted in the rotary furnace and chamber kiln at the temperature of $900^{\circ} \mathrm{C}$ in air atmosphere

\begin{tabular}{|c|c|c|c|c|}
\hline \multirow{3}{*}{ Material } & \multicolumn{2}{|c|}{ Content of Ca [wt \%] } & \multicolumn{2}{c|}{ Content of P [wt \%] } \\
\cline { 2 - 5 } & Rotary furnace & $\begin{array}{c}\text { Furnace } \\
\text { kiln }\end{array}$ & $\begin{array}{c}\text { Rotary } \\
\text { furnace }\end{array}$ & $\begin{array}{c}\text { Furnace } \\
\text { kiln }\end{array}$ \\
\hline Mixture III & 35.4 & 36.7 & 16.1 & 16.5 \\
\hline
\end{tabular}

The X-Ray spectra for the samples (Fig. 7) shows that ash contains hydroxyapatite without impurities. An increase in the temperature of the roasting of the materials results in an increased degree of hydroxyapatite crystallinity, which is reflected in an increase in the number of counts in the presented diffractograms. The degree of hydroxyapatite crystallinity in ash coming from the rotary furnace is lower than that of the chamber kiln what is noticed in diffractograms and figures (Fig. 8).

The analyses of the physicochemical properties of raw bone waste have demonstrated that it contains approximately $10 \mathrm{wt} \%$ phosphorus and $20 \mathrm{wt} \%$ calcium, humidity $40-50 \mathrm{wt} \%$. Hydroxyapatite is the only crystalline

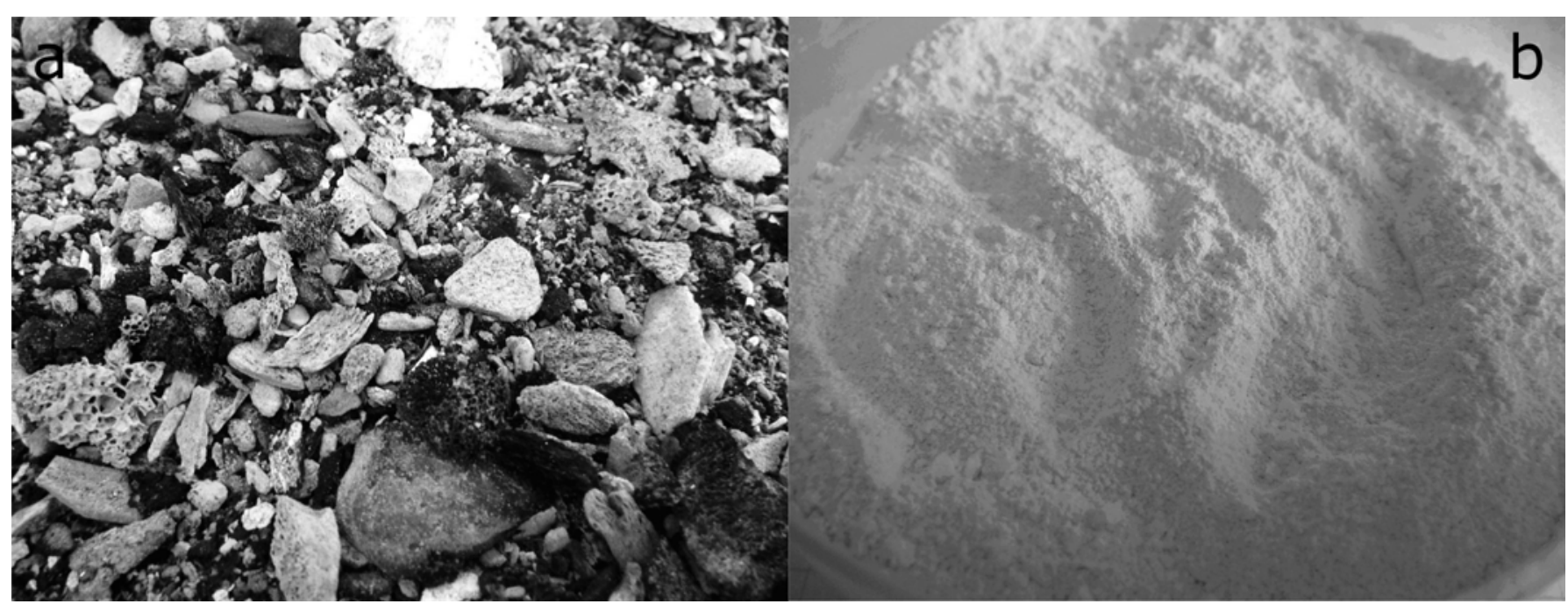

Figure 8. Ash: a - calcining of the mixture of bone waste in the rotary furnace at the temperature of $900^{\circ} \mathrm{C}, \mathrm{b}-\mathrm{after}$ comminution and second roasting 
phase present in the obtained ashes. The heat of the combustion for bone sludge and pulp is comparable and on average $7.6[\mathrm{MJ} / \mathrm{kg}]$. The heat of combustion for bovine bones and pork bones is greater (appropriately: 13 and 17 $[\mathrm{MJ} / \mathrm{kg}])$. Pork bones have the greatest heat of combustion because of the content of fats and it is comparable with the heat of combustion of power coal (brown coal).

\section{CONCLUSION}

The analyses of the prepared mixtures of bone waste demonstrate their similar values of the heat of combustion (from 11 to $12.5[\mathrm{MJ} / \mathrm{kg}]$ ). The products of the calcining of the mixtures contain on average $36 \mathrm{wt} \%$ of calcium and $16.5 \mathrm{wt} \%$ phosphorus (it is comparable with natural phosphate deposits). The phase composition is the same for ash and raw material in respect of the quality of the composition. Hydroxyapatite is the only crystalline phase in the analyzed material. Temperature influences the degree of crystallinity (the highest temperature, the greater amount of degree of crystallinity).

\section{ACKNOWLEDGEMENT}

This work is supported by the Grant of the Minister of Science and Higher Education No 1850/B/H03/2009/36

\section{LITERATURE CITED}

1. Karcz, H. \& Kozakiewicz, A. (2007). The way of thermal utilization of animal waste. Energetyka i Ekologia, 11, 823 829 (in Polish).

2. Karcz, H. Thermal utilization of Animals waste. (2005). Energetyka i Ekologia, 3, 173 - 181 (in Polish).

3. Regulation of the Minister of Economy, Labour and Social Policy of 22 December 2003 amending the Regulation on the requirements for the process of thermal conversion of waste, Dz. U. z 2004 Nr 1, poz. 2 (in Polish).

4. Regulation of the Minister of Agriculture and Food Economy of 23 December 1998 on detailed conditions of veterinary collection, processing, burying or burning of animal carcasses and their parts and slaughterhouse waste, Dz. U. z $1999 \mathrm{Nr}$ 3, poz. 23 (in Polish).

5. Directive 2000/76/CE of European Parliament about waste incineration.

6. Kowalski, Z., Wzorek Z., Kulczycka J. \& Góralczyk M. (2005). Meat waste management. Conference proceedings: The Conference on Industrial Pollution and Sustainable Development, 14-17 December, Maribor, Slovenia.

7. Kowalski, Z. \& Krupa-Żuczek, K. (2007). Model solutions of wasteless management of meat waste. LAB, 5, 20-27 (in Polish).

8. Regulation of the Minister of Economy of 29 January 2002 on the types of non-hazardous waste and the types of installations and facilities in which they can be thermal converted, Dz. U. z $2002 \mathrm{Nr}$ 18, poz. 176 (in Polish).

9. Council Directive 96/23/WE of 29 April 1996 on measures to monitor certain substances and residues thereof in live animals and animal products (in Polish).

10. Council Directive 96/22/WE of 29 April 1996 concerning the prohibition on the use of certain substances having a hormonal action, action and beta-agonists action on livestock (in Polish).

11. Wilkosz-Język, A. (2007). Receiving of calcium phosphate from meat-bone meal. Doctor's thesis, Cracow University of Technology (in Polish).

12. Krupa-Żuczek, K., Kowalski Z. \& Wzorek Z. (2007). Directions of treatment of bone semi-products and bone waste from meat industry. Recyklace Odpadu XI, Slovenska Akademia Vied Kosice, Slovak Republic, 06-07.12.2007, 57 66 (in Polish).

13. PN-88/C-87015. Fertilizers. Methods of investigation of phosphates content (in Polish).

14. PN-97/R-64803. Feed. Feed phosphates (in Polish).

15. PN-81/G04513. Solid fuel. Determination of heat of combustion and calculation calorific value (in Polish).

16. Brandt, S. (2002). Data analysis - statistical and analytical methods. Warsaw (in Polish). 